\title{
Characterization of Pubertal Development Phases in Female Longtooth Grouper, Epinephelus bruneus via Classification of Bodyweight
}

\author{
Yong-Woon Ryu, Sang-Woo Hur ${ }^{\dagger}$, Sung-Pyo Hur, Chi-Hoon Lee, \\ Bong-Soo Lim and Young-Don Lee \\ Marine and Environmental Research Institute, Jeju National University, Jeju 695-965, Korea
}

\begin{abstract}
Puberty is the developmental period which animals obtain the ability of reproducing sexually for the first time in life. In commercially important aquaculture fish species, the onset of puberty is a matter of major interest due to controlling of sexual maturation to improve broodstock management. To investigate pubertal characteristics of female longtooth grouper (Epinephelus bruneus), specimens were classified into three groups by the bodyweight, including 1, 2, and $3 \mathrm{~kg}$ group. Thereafter, we focused on ovarian development and level changes of endocrine regulation factors (GnRH, GTHs, steroid hormone). In the non-breeding season (April), the levels of endocrine regulation factors showed increasing trends in accordance with bodyweight gaining; nevertheless, the oocytes were growth phase belongs to almost peri-nucleous stages in all groups. In the breeding season (June), the levels of endocrine regulation factors were fluctuated that decreases in levels of sbGnRH and FSH $\beta$ mRNA expressions along with serum $\mathrm{E}_{2}$ concentrations in $3 \mathrm{~kg}$ of group. However, $\mathrm{LH} \beta$ mRNA expression levels sustained increasing trends by the bodyweight. Moreover, the oocytes developed that $2 \mathrm{~kg}$ and $3 \mathrm{~kg}$ groups obtained plentiful vitellogenic oocytes while $1 \mathrm{~kg}$ group was still composed with greater part of pre-vitellogenic oocytes. Especially, the oocytes of $3 \mathrm{~kg}$ group reached over $450 \mu \mathrm{m}$ of diameters that indicating possibility to enter the final maturations. These results suggest that the progress of pubertal development in female E. bruneus could be classify into three phases via bodyweight, including pre-puberty $(1 \mathrm{~kg})$, early-puberty $(2 \mathrm{~kg})$ and puberty $(3 \mathrm{~kg})$.
\end{abstract}

Key words : Puberty, Longtooth grouper, Oocyte development, Bodyweight, GnRH, GTH subunits

\section{INTRODUCTION}

Puberty is the period which their sexual organs develop and become capable of having reproductive ability for the first time. Pubertal development in fish is mainly regulated by the system, so called brain-pituitary-gonad (BPG) axis (Schulz \& Goos, 1999; Okuzawa, 2002; Patiño \& Sullivan, 2002).

Gonadotropin releasing hormone $(\mathrm{GnRH})$ is a primary factor in the BPG axis, further two and more generally three forms are present within a vertebrate and between species these forms can vary in their location of expression

\footnotetext{
${ }^{\dagger}$ Corresponding author: Sang-Woo Hur, Marine and Environmental Research Institute, Jeju National University, 3288 Hamdeok, Jocheon, Jeju, Jeju Special Self-Governing Province 695-965, Korea. Phone: +82-64-783-9260, Fax: +82-64-783-6066, E-mail: maverickhuh@jejunu. ac.kr
}

within the brain (Weltzien et al., 2004; Whitlock et al., 2006). Several types of GnRHs have also been discovered in fish, especially a type of GnRH produced from preoptic area is known that regulates synthesis and release of gonadotropin (GTH) (Oka, 1997; Goos et al., 1998; Okuzawa \& Kobayashi, 1999). Moreover, the implication of GnRH expressions in pubertal development has been suggested with some fish (Holland et al., 2001; Okuzawa et al., 2003). In the pituitary, GnRH neurons innervate gonadotrophs in order to release two types $\beta$-subunit of GTHs, i.e., follicle stimulating hormone- $\beta$ (FSH $\beta$ ) and luteinizing hormone$\beta$ ( $\mathrm{LH} \beta$ ). The relative importance between both subunits on pubertal development of fish was often compared in many studies; nevertheless, those critical roles and/or significance are unclear (Okuzawa, 2002). The released GTHs regulate gonadal activities such as gametogenesis and steroi- 
dogenesis (Nagahama, 2000). In the gonads, subsequent steroid hormones, representatively estradiol-17 $\beta\left(\mathrm{E}_{2}\right)$ in female, are produced by the actions of GTHs and other stimulating hormones, and the increasing of their activity becomes a reason for gonadal development. Overall, the possible roles of such factors in fish reproduction are generally well-known at the present day, whereas the mechanisms of systematic circulations of these factors are still not fully understood. Therefore, observation of level changes in endocrine regulation factors underlying BPG axis is very important tools to understand pubertal development mechanisms.

Initiation of puberty in fish is correlated with the attainment of a threshold bodyweight (Huang et al., 1998). A number of studies have been suggested that age and body growth are deeply concerned with pubertal development in fish, and it varies from species to species to reach the puberty (Le Bail, 1988; Le Gac et al., 1993; Amano et al., 1997a; Taranger et al., 2010).

The longtooth grouper, Epinephelus bruneus is one of the very commercially valuable species in Korea (Lee et al., 2008; Sao et al., 2012). However, it is a protogynous hermaphrodite, and takes a long time to reach the puberty. These make it difficult to manage the broodstock and to understand the sexual characteristics of this species. Thus, classification by the bodyweight seemed suitable to understand the characteristics of pubertal development progress, further application to controlling of puberty. To achieve that, we investigated the level changes of $\mathrm{GnRH}$ gene $(\mathrm{sbGnRH})$ in the brain, gonadotropin subunit genes $(\mathrm{FSH} \beta$ and $\mathrm{LH} \beta$ ) in the pituitary and serum concentration levels of steroid hormone $\left(\mathrm{E}_{2}\right)$, furthermore the gonadal development was observed during the process of pubertal development in female E. bruneus.

\section{MATERIALS AND METHODS}

\section{Experimental fish}

Experimental fish were classified into three groups, approximately $1 \mathrm{~kg}$ group $(1.1 \pm 0.1 \mathrm{~kg}), 2 \mathrm{~kg}$ group $(2.3 \pm 0.2$ $\mathrm{kg})$, and $3 \mathrm{~kg}(3.3 \pm 0.2 \mathrm{~kg})$ group, according to the bodyweight. Specimens were individually marked via insertion of micro-tag (Trovan Electronic Identification System, USA) into the dorsal skin, and were maintained indoor rearing tank $(6.5 \times 11 \times 3 \mathrm{~m})$ under flow-through system. Two female fish in each group were collected on non-breeding season (April) and breeding season (June). Fish were anesthetized with 2-phenoxyethanol (Sigma Co., USA; 20 ppm), then weighed and bled from caudal vein. Each target tissues were collected by suitable methods as described below.

\section{Histological observation}

The gonads were removed from the abdominal cavity and fixed in Bouin's solution for histological observation. Tissues were dehydrated in a graded series of ethanol, embedded in paraffin and then cut into $7 \mu \mathrm{m}$ cross sections. Slides were stained with Hansen's hematoxylin and 0.5\% eosin then observed using a light microscope (HBO 50, Carl Zeiss).

3. Quantification of the mRNA levels by real-time RT-PCR

The brain and pituitary were frozen in liquid nitrogen and then stored $-80^{\circ} \mathrm{C}$ until extraction of total RNA. Total RNAs were isolated using RNAiso reagent (Takara, Co., Japan) following the manufacturer's directions. Moreover, added Ethachinmate to aqua-phase on precipitation for carrier. Both quantitative and qualitative analyses of total RNAs were performed by Optizen 2120 UV spectrometer (Mecasys Co., Korea) and Nanodrop 1000 (Thermo Scientific, Waltham, MA, USA). Reverse transcript reactions contained $5 \mu \mathrm{g}$ total RNA in Diethyl-pyrocarbonate (DEPC) distilled water. Total RNAs were heated at $65^{\circ} \mathrm{C}$ for $10 \mathrm{~min}$, then immediately chill on ice for 2 minute. The reactions were added with $0.5 \mu$ g Oligo-dT15-mer (Promega, USA) primer in Ready-To-Go-You-Prime First-Strand Beads (GE Healthcare, UK) kit. The reactions were incubated at $37^{\circ} \mathrm{C}$ for $60 \mathrm{~min}$ for cDNA synthesis. Primers for quantitative real-time PCR analysis were based on cDNA sequences for E. bruneus 
Table 1. Oligonucleotide primers used in real time quantitative RT-PCR

\begin{tabular}{|c|c|c|c|}
\hline Gene & & Oligonucleotide primers & Product length $(\mathrm{bp})$ \\
\hline \multirow{3}{*}{ sbGnRH } & Forward primer & 5'-TGGACAGTCTCTCAGAAACACC-3' & \\
\hline & Taqman probe & 5'-TGGCAAAAGGTGATTCCTCCACACAA-3' & 135 \\
\hline & Reverse primer & 5'-CACTGTCAAGAAATCCTTTGGTTC-3' & \\
\hline \multirow{3}{*}{$\mathrm{FSH} \beta$} & Forward primer & 5'-CTGCCACTCCGACTGTCATC-3' & \\
\hline & Taqman probe & 5'-ACCAGCATCAGCATCCCTGTGGAGA-3' & 101 \\
\hline & Reverse primer & 5'-GGTAACACTGTCCTTCACATATGG-3' & \\
\hline \multirow{3}{*}{$\mathrm{LH} \beta$} & Forward primer & 5'-TTTGAGCTTCCTGACTGTCCTC-3' & \\
\hline & Taqman probe & 5'-ACCCGACTGTCACCTACCCTGTGGC-3' & 115 \\
\hline & Reverse primer & 5'-GGCTCTCGAAGGTGCAGTC-3' & \\
\hline
\end{tabular}

sbGnRH, FSH $\beta$ and LH $\beta$ (GeneBank accession number: FJ380047, EF583919, EF583920). The primer sequences and product sizes are shown Table 1. Twenty-five $\mu$ of real time RT-PCR reaction mixtures contained $12.5 \mu \mathrm{l}$ of IQ supermix (Bio-Rad, USA), $5 \mu$ of cDNA, $1 \mu$ l (500 $\mathrm{nM}$ ) of each primer and probe. The PCR amplification was carried out on an Chromo 4TM Four-Color Real-Time System (Bio-rad, USA) as follows: denaturation at $50^{\circ} \mathrm{C}$ for $2 \mathrm{~min}$ and then $95^{\circ} \mathrm{C}$ for $3 \mathrm{~min}, 45$ cycles of denaturation at $95^{\circ} \mathrm{C}$ for $15 \mathrm{sec}$, annealing at $60^{\circ} \mathrm{C}$ for $1 \mathrm{~min}$. Each sample was analyzed in duplicate.

\section{Determination of the steroid hormones by RIA}

Serum $E_{2}$ levels were measured by radioimmunoassay followed by Aida et al. (1984). Minimum detectable limit was $12.73 \mathrm{pg} / \mathrm{ml}$. Intra-assay and inter-assay coefficients of variance were $6.02 \%(n=3)$ and $9.20 \%(n=6)$ on assays.

\section{Statistical analysis}

All data were represented as means \pm standard error and subjected to one-way ANOVA analysis of variance followed Duncan's multiple range test (Duncan, 1955). Differences were considered at $P<0.05$.

\section{RESULTS}

\section{Level changes of endocrine regulation factors}

In the quantification of sbGnRH and GTHs mRNA expression levels, significant differences between the seasons were not observed in all groups except sbGnRH mRNA levels in $1 \mathrm{~kg}$ group (Fig. 1). The expression levels of sbGnRH in non-breeding season showed increasing trends in accordance with bodyweight gaining; especially, large variation was observed in $3 \mathrm{~kg}$ group. On the contrary, there were no remarkable level changes in breeding season (Fig. 1A). The expression levels of both GTH subunits also showed increasing trends with bodyweight gaining. In both seasons, the $\mathrm{FSH} \beta$ mRNA levels rapidly increased from $2 \mathrm{~kg}$ groups although the lower level than non-breeding season was observed in $3 \mathrm{~kg}$ group (Fig. 1B). The LH $\beta$ mRNA levels showed clear increasing trends by the bodyweights and the levels of all groups in breeding season were higher than non-breeding season (Fig. 1C).

Likewise the serum concentration of $\mathrm{E}_{2}$ showed increasing levels coinciding with bodyweight gaining. The level of 3 $\mathrm{kg}$ group was dramatically increased in the non-breeding season, as compared to the moderate level seen in breeding season. The significant differences were also observed in 2 $\mathrm{kg}$ and $3 \mathrm{~kg}$ groups between the seasons; the level of $2 \mathrm{~kg}$ group in breeding season was significantly higher than non-breeding season, however the trend was reversed in 3 $\mathrm{kg}$ group that the level in non-breeding season was higher than breeding season (Fig. 2). 


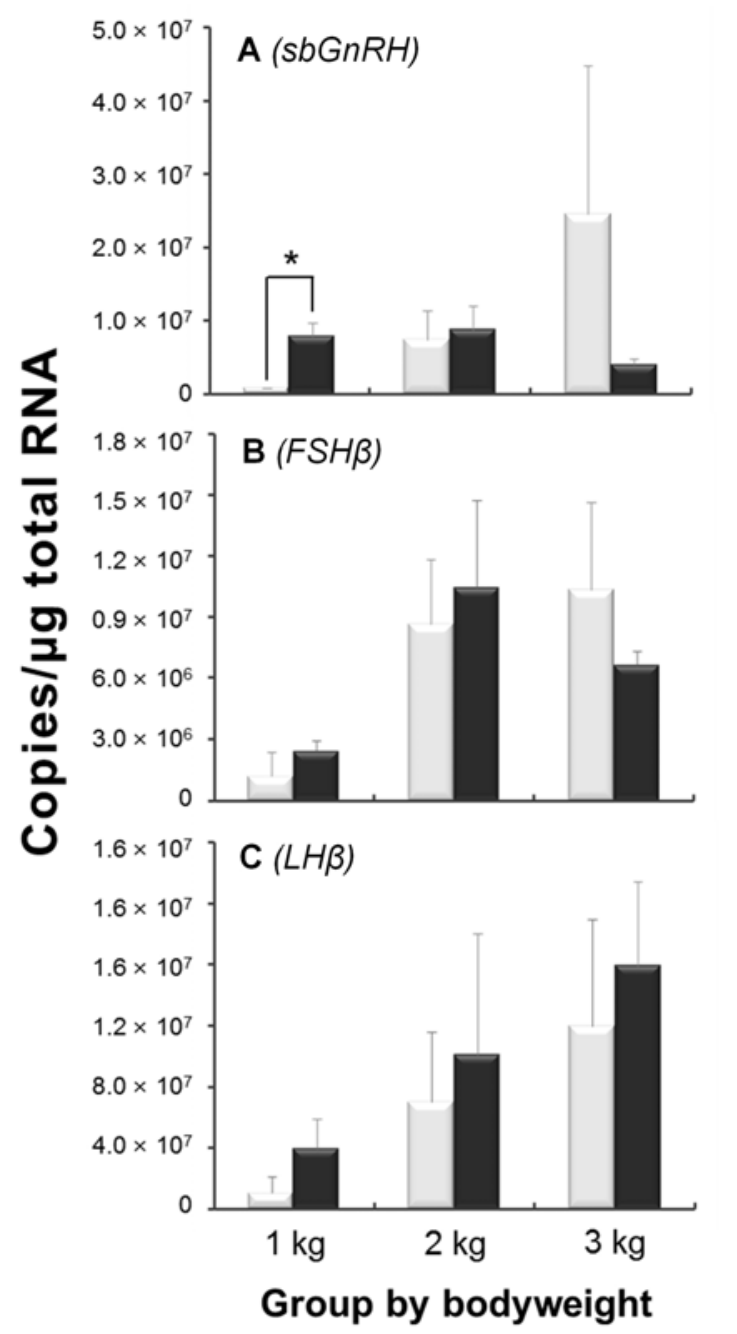

4 Non-breeding season Breeding season

Fig. 1. Level changes of sbGnRH and GTHs mRNA expressions in female Epinephelus bruneus during pubertal development progress. The groups are classified by bodyweight. (A) sbGnRH mRNA, (B) FSH $\beta$ mRNA, and (C) LH $\beta$ mRNA levels in non-breeding (April) and breeding season (June) indicated. Data are expressed as means \pm standard error. Asterisk means significant differences $(P<0.05)$.

\section{Gonadal development}

In the non-breeding season, the ovaries of both $1 \mathrm{~kg}$ and $2 \mathrm{~kg}$ groups were mostly composed under peri-nucleous stage oocytes. The $1 \mathrm{~kg}$ group contained peri-nucleous oocytes having approximately $80 \mu \mathrm{m}$ of diameter (Fig. 3A), and 2 $\mathrm{kg}$ group showed similar gonadal development phase while

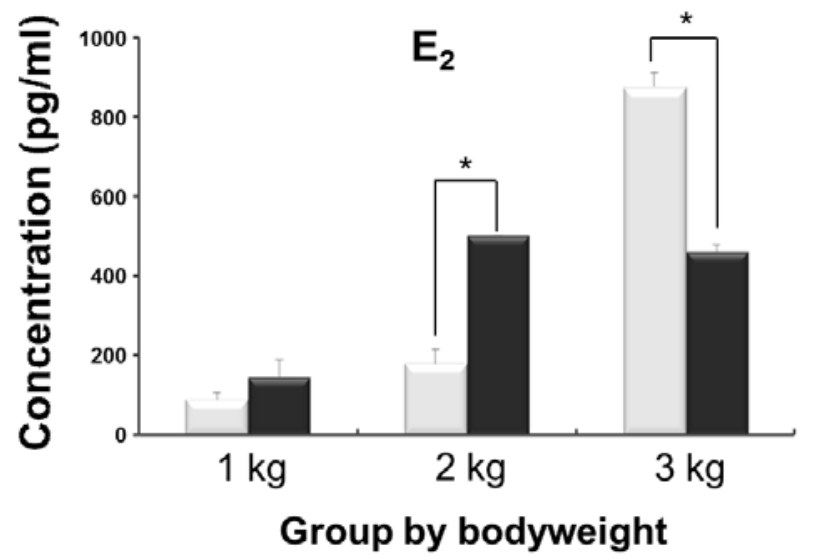

$\square$ Non-breeding season $\square$ Breeding season

Fig. 2. Plasma concentration levels of estradiol-17 $\beta\left(\mathbf{E}_{2}\right)$ in female Epinephelus bruneus during pubertal development progress. The groups are classified by bodyweight. Data are expressed as means \pm standard error. Asterisk means significant differences $(P<0.05)$.

the oocytes were homogenous sizes than $1 \mathrm{~kg}$ (Fig. 3B). In the ovaries of $3 \mathrm{~kg}$ group, more developed oil-droplet stage oocytes with approximate $150 \mu \mathrm{m}$ of diameter were observed (Fig. 3C).

In the breeding season, $1 \mathrm{~kg}$ group still contained perinucleous oocytes and partly oil-droplet oocytes (Fig. 3D). On the contrary, the ovary of $2 \mathrm{~kg}$ group was matured than $1 \mathrm{~kg}$ group showing vitellogenic oocytes accumulated abundant yolk granules within ooplasm (Fig. 3E). Among the groups, the $3 \mathrm{~kg}$ group showed most matured ovary that composed greater part of vitellogenic oocytes of approximately $450 \mu \mathrm{m}$ diameter (Fig. 3F).

\section{DISCUSSION}

Puberty in fish is regulated by some key factors, such as GnRHs, GTHs and steroid hormones, involving activation of BPG axis. Nevertheless, the mechanisms underlying the initiation of puberty are still unclear. Therefore, in this study, we have attempted to characterize the pubertal development phases of female E. bruneus, based on the expression patterns of such endocrine regulation factors in 

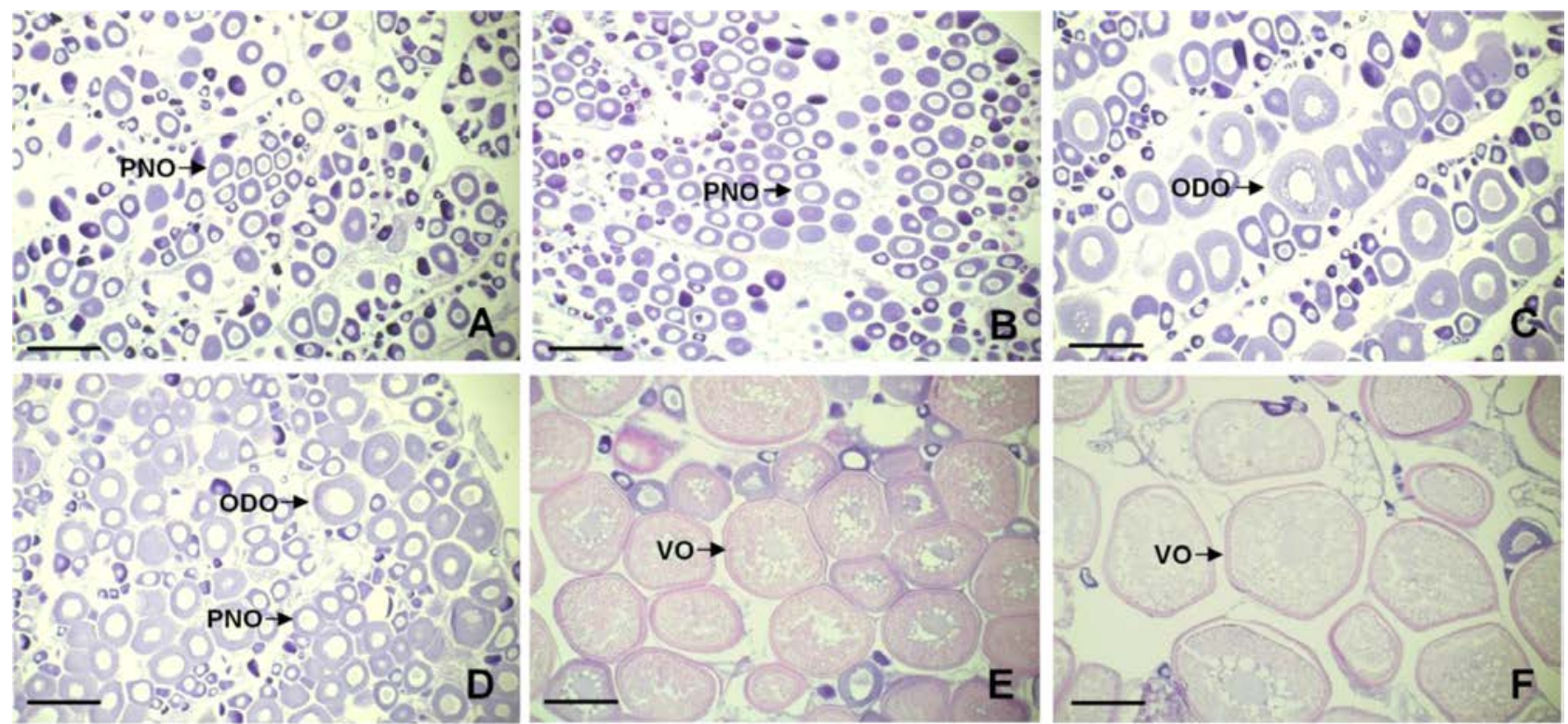

Fig. 3. Variations of oocyte development phases in ovary of female Epinephelus bruneus during pubertal development progress. Peri-nucleous stage in $1 \mathrm{~kg}$ (A) and $2 \mathrm{~kg}$ (B), and oil-droplet stage in $3 \mathrm{~kg}$ (C) were observed in non-breeding season (April). Under oil-droplet stage oocytes were composed in ovary of $1 \mathrm{~kg}(\mathrm{D})$, and large numbers of vitellogenic oocytes were observed in $2 \mathrm{~kg}$ (E) and $3 \mathrm{~kg}$ (F) in breeding season (June). PNO: Peri-nucleous oocyte; ODO: Oil-droplet oocyte; VO: Vitellogenic oocyte. Scale bar $=200 \mu \mathrm{m}$.

accordance with bodyweight gaining.

Fish have several types of GnRHs (Lethimonier et al., 2004). It has been reported that three forms of GnRH are representative in perciformes, i.e., red seabream type of $\mathrm{GnRH}(\mathrm{sbGnRH})$, salmon type of $\mathrm{GnRH}(\mathrm{sGnRH})$ and chicken type of GnRH (cGnRH-II) (Amano et al., 1997b). Especially, sbGnRH are known as major type for reproduction in perciformes species (Senthilkumaran et al., 1999; Pham et al., 2006). Thus, seabream type of GnRH was previously cloned from the brain of E. bruneus (data not shown) and the mRNA expression levels were investigated in this study. The expression levels of sbGnRH mRNA showed increasing trend during the progress of pubertal development in non-breeding season. Such patterns were also observed in other species, such as Oncorhynchus masou, Pagrus major, Dicentrarchus labrax and Morone saxatilis (Amano et al., 1997a; Rodríguez et al., 2000; Holland et al., 2001; Okuzawa et al., 2003) during pubertal development, indicating that activation of sbGnRH expressions is possible to be trigger of onset and development of puberty. In the breeding season, however, remarkable levels increasing of sbGnRH expression was not observed, and the level was lower than non-breeding season in $3 \mathrm{~kg}$ of group. This result suggests that peak of sbGnRH mRNA expression in breeding season was already completed, and consequently decreased at low levels in around $3 \mathrm{~kg}$ of female E. bruneus. Evidently, the expressions of sbGnRH were decreased when they finished pubertal development in many perciformes (Senthilkumaran et al., 1999; Collins et al., 2001; Okuzawa et al., 2003). Therefore, the peak of sbGnRH mRNA expressions in non-breeding season of $3 \mathrm{~kg}$ group seemed a sign the entry to puberty in female E. bruneus.

The teleosts GTHs are assumed as key factors for regulating gonadal maturation (Weltzien et al., 2004). In the present study, both FSH $\beta$ and $\mathrm{LH} \beta$ mRNA expression levels exhibited increasing trends through the progress of pubertal development along with bodyweight gaining. In general, FSH is supposed that has more important influence than 
LH on pre-pubertal and early pubertal development in teleosts. However, those crucial roles in onset of puberty still remained as controversial issue due to the levels varying degree with species. The superior levels of FSH $\beta$ compared with $\mathrm{LH} \beta$ during early puberty have been reported in O. masou, Oncorhynchus mykiss and M. saxatilis (Amano et al., 1992; Gomez et al., 1999; Hassin et al., 1999; 2000). On the contrary, relative importance of $\mathrm{LH} \beta$ gene expressions on progress of puberty was also reported in D. labrax and P. major (Gen et al., 2000; Rodríguez et al., 2000). In this study, the $\operatorname{LH} \beta$ expressions sustained increasing trend, further the absolute copy numbers were higher than $\mathrm{FSH} \beta$ during pubertal progress. These phenomena mean the roles of $\mathrm{LH} \beta$ on puberty may be important at least in E. bruneus, although the wide variety with fish species remained to be verified yet.

One of the potential factors effecting on the initiation and development of puberty in several fish species appeared to be gonadal sex steroids (Okuzawa, 2002); an increase in the plasma $\mathrm{E}_{2}$ levels was coincided with sexual maturation (Campbell et al., 2006). Such increase in plasma $E_{2}$ associating with the initiation and progress of oocyte development phase has also been reported in Carassius auratus and Danio rerio (Khoo, 1979; Kwok et al., 2005). Thus, the increased levels of $E_{2}$ in this study seem to support the promoting effects of $E_{2}$ on the pubertal development of female E. bruneus. Moreover, the decrease in levels of 3 $\mathrm{kg}$ on breeding season is supposed the positive influence by feedback of steroid hormones; because this group seemed already enter the puberty phase.

The level changes of endocrine regulation factors which described above are directly reflected on the oocytes developments. In the histological observations, we could confirm clear differences with oocyte developmental stages by the bodyweight gaining as well as pubertal development progress. In the non-breeding season, remarkable differences could not observed among the groups, while the definite differences appeared with $2 \mathrm{~kg}$ and $3 \mathrm{~kg}$ groups in breeding season; notably, the oocytes contained $3 \mathrm{~kg}$ group were most matured. These are supposed immediate evidences that consequent on the expressions of endocrine factors. Because, it is well-known that the combinations of increases in $\operatorname{FSH} \beta$ and $\mathrm{E}_{2}$ levels stimulate oocyte development in several fish species (Campbell et al., 2006). Therefore, high expressions of FSH $\beta$ mRNA and serum $E_{2}$ levels of $3 \mathrm{~kg}$ groups in non-breeding season are involved in accumulation of lipids and vitellogenin into oocytes, resulting reach the oocyte maturation in breeding season.

Taken together, $1 \mathrm{~kg}$ of female E. bruneus was classified pre-pubertal stage, charactering any endocrine regulation factors still not fully expressed and the ovary was composed under peri-nucleous oocytes. On the other hand, $2 \mathrm{~kg}$ and $3 \mathrm{~kg}$ groups can be classified early-pubertal stage based on the sufficient levels in endocrine regulation factors and matured oocytes. However, we supposed that $3 \mathrm{~kg}$ group is already possible to spawn (puberty phase), because that having over $450 \mu \mathrm{m}$ oocytes in gonads which is essential requirement for inducing of final oocyte maturation in reared groupers (Marino et al., 2003; Lee et al., 2008). In general, rearing condition is not suitable to complete gametogenesis in groupers owing to insufficient of environmental cues. Thus, if suitable solutions be provided, e.g. hormonal treatments, the $3 \mathrm{~kg}$ group will achieve the final oocyte maturation

In summarized, our results indicate that pubertal development progress in female E. bruneus is able to classify following three phases; pre-puberty ( $1 \mathrm{~kg}$ ), early-puberty $(2 \mathrm{~kg})$ and puberty $(3 \mathrm{~kg})$. Moreover, this research useful in future works to control of puberty that is necessary for the successful management of broodstock in E. bruneus.

\section{REFERENCES}

Aida K, Kato T, Awaji M (1984) Effects of castration on the smoltification of precocious male masu salmon Oncorhynchus masou. Bull Jpn Soc Sci Fish 50:565-571.

Amano M, Aida K, Okumoto N, Hasegawa Y (1992) Changes in salmon GnRH and chicken GnRH-II contents in the 
brain and pituitary, and GTH contents in the pituitary in female masu salmon, Oncorhynchus masou, from hatching through ovulation. Zool Sci 9: 375-386.

Amano M, Kitamura S, Ikuta K, Suzuki Y, Aida K (1997a) Activation of salmon GnRH mRNA expression prior to differentiation precocious males in masu salmon. Gen Comp Endocrinol 105:365-371.

Amano M, Urano A, Aida K (1997b) Distribution and function of gonadotropin-releasing hormone $(\mathrm{GnRH})$ in the teleost brain. Zool Sci 14:1-11.

Campbell B, Dickey J, Beckman B, Young G, Pierce A, Fukada H, Swanson P (2006) Previtellogenic oocyte growth in salmon: relationships among body growth, plasma insulin-like growth factor-1, estradiol-17 $\beta$, folliclestimulating hormone and expression of ovarian genes for insulin-like growth factors, steroidogenic-acute regulatory protein and receptors for gonadotropins, growth hormone, and somatolactin. Biol Reprod 75:34-44.

Collins PM, O'Neill DF, Barron BR, Moore RK, Sherwood NM (2001) Gonadotropin-releasing hormone content in the brain and pituitary of male and female grass rockfish (Sebastes rastrelliger) in relation to seasonal changes in reproductive status. Biol Reprod 65:173-179.

Duncan DB (1955) Multiple-range test and multiple F test. Biometrics 11:1-42.

Gen K, Okuzawa K, Senthilkumaran B, Tanaka H, Moriyama S, Kagawa H (2000) Unique expression of gonadotropin-I and-II subunit genes in male and female red seabream (Pagrus major) during sexual maturation. Biol Reprod 63:308-319.

Gomez JM, Weil C, Ollitrault M, Le Bail P-Y, Breton B, Le Gac F (1999) Growth hormone (GH) and gonadotropin subunit gene expression and pituitary and plasma changes during spermatogenesis and oogenesis in rainbow trout (Oncorhynchus mykiss). Gen Comp Endocrinol 113: 413-428.

Goos HJT, Blomenröhr M, Bogerd J, Bosma PT, Li KW, Okuzawa K, Rebers FEM, Shulz RW, Tensen CP, Zandbergen MA (1998) Gonadotropin-releasing hormones and their receptors in fish. In: Vaudry $\mathrm{H}$ et al. (eds.), Trends in Comparative Endocrinology and Neurobiology: from Molecular to Integrative Biology, Annals of the New York Academy of Sciences. Blackwell, New York, pp. 41-46.

Hassin S, Gothilf Y, Blaise O, Zohar Y (1998) GonadotropinI and -II subunit gene expression of male striped bass (Morone saxatilis) after gonadotropin-releasing hormone analogue injection: quantitation using an optimized ribonuclease protection assay. Biol Reprod 58:1233-1240.

Hassin S, Holland MCH, Zohar Y (2000) Ontogeny of follicle-stimulating hormone and luteinizing hormone gene expression during pubertal development in the female striped bass, Morone saxatilis (Teleostei). Biol Reprod 61:1608-1615.

Holland MCH, Hassin S, Zohar Y (2001) Seasonal fluctuations in pituitary levels of the three forms of gonadotropinreleasing hormone in striped bass, Morone saxatilis (Teleostei), during juvenile and pubertal development. J Endocrinol 169: 527-538.

Huang YS, Rousseau K, Belle NL, Vidal B, BurzawaGerard E, Marchelidon J, Dufour S (1998) Insulin-like growth factor-I stimulates gonadotrophin production from eel pituitary cells: a possible metabolic signal for induction of puberty. J Endocrinol 159:43-52.

Khoo KH (1979) The histochemistry and endocrine control of vitellogenesis in goldfish ovaries. Can J Zool 57: 617-626.

Kwok H, So W, Wang Y, Ge W (2005) Zebrafish gonadotropins and their receptors: I. cloning and characterization of zebrafish follicle-stimulating hormone and luteinizing hormone receptors-evidence for their distinct functions in follicle development. Biol Reprod 72:1370-1381.

Le Bail PY (1988) Growth-reproduction interaction in salmonids: Reproduction in fish-basic and applied aspects in endocrinology and genetics. In: Proc. French Israeli Symposium, Tel Aviv, Israel, 10-12 Nov, 1986, pp 91108.

Le Gac F, Blaise O, Fostier A, Le Bail P-Y, Loir M, 
Mourot B, Weil C (1993) Growth hormone (GH) and reproduction: a review. Fish Physiol Biochem 11:219232.

Lee YD, Song YB, Lim BS, Oh SR, Kim HB (2008) Grouper aquaculture research in Jeju Island, Korea. In: Liao IC, Leaño EM, eds. The Aquaculture of Groupers, World Aquacult Soc, p49-60, USA.

Lethimonier C, Madigou T, Munoz-Cueto JA, Lareyre JJ, Kah O (2004) Evolutionary aspects of GnRHs, GnRH neuronal systems and GnRH receptors in teleost fish. Gen Comp Endocrinol 135:1-16.

Marino G, Panini E, Longobardi A, Mandich A, Finoia MG, Zohar Y, Mylonas CC (2003) Induction of ovulation in captive-reared dusky grouper, Epinephelus marginatus (Lowe, 1834), with a sustained-release GnRHa implant. Aquaculture 219:841-858.

Nagahama Y (2000) Gonadal steroid hormones: major regulators of gonadal sex differentiation and gametogenesis in fish. In: Proc. 6th International Symposium on Reproductive Physiology of Fish, Bergen, Norway, 4-9 Jul, 1999, pp 211-222.

Oka Y (1997) GnRH neuronal system of fish brain as a model system for the study of peptidergic neuromodulation. In: Parhar IS, Sakuma Y (eds.), GnRH Neurons Gene to Behavior. Brain Shuppan, Tokyo, pp 245-276.

Okuzawa K, Kobayashi M (1999) Gonadotropin-releasing hormone neuronal systems in the teleostean brain and functional significance. In: Prasada Rao PD, Peter RE (eds.), Neural Regulation in the Vertebrate Endocrine System. Kluwer Academic/Plenum Publishers, New York, pp 85-100.

Okuzawa K (2002) Puberty in teleosts. Fish Physiol Biochem 26:31-41.

Okuzawa K, Gen K, Bruysters M, Bogerd J, Gothilf Y, Zohar Y, Kagawa H (2003) Seasonal variation of the three native gonadotropin-releasing hormone messenger ribonucleic acids levels in the brain of female red seabream. Gen Comp Endocrinol 130:324-332.
Patiño R, Sullivan CV (2002) Ovarian follicle growth, maturation, and ovulation in teleost fishes. Fish Physiol Biochem 26:57-70.

Pham KX, Amano M, Amiya N, Kurita Y, Yamamori K (2006) Distribution of three GnRHs in the brain and pituitary of the wild Japanese flounder Paralichthys olivaceus. Fish Sci 72:89-94.

Rodríguez L, Carrillo M, Sorbera LA, Soubrier MA, Mañanós E, Holland MCH, Zohar Y, Zanuy S (2000) Pituitary levels of three forms of GnRH in the male European sea bass (Dicentrarchus labrax L.) during sex differentiation and first spawning season. Gen Comp Endocrinol 120: 67-74.

Sao PN, Hur SW, Lee CH, Lee YD (2012). Gonadal sex differentiation of hatchery-reared longtooth grouper (Epinephelus bruneus). Dev Reprod 16: 185-193.

Schulz RW, Goos HJT (1999) Puberty in male fish: concepts and recent developments with special reference to the African catfish (Clarias gariepinus). Aquaculture 177: 5-12.

Senthilkumaran B, Okuzawa K, Gen K, Ookura T, Kagawa H (1999) Distribution and seasonal variations in levels of three native GnRHs in the brain and pituitary of perciform fish. J Neuroendocrinol 11:181-186.

Taranger GL, Carrillo M, Schulz RW, Fontaine P, Zanuy S, Felip A, Weltzien FA, Dufour S, Karlsen O, Norberg B, Andersson E, Hansen T (2010) Control of puberty in farmed fish. Gen Comp Endocrinol 165:483-515.

Weltzien FA, Andersson E, Andersen Ø. Shalchian-Tabrizi K, Norberg B (2004) The brain-pituitary-gonad axis in male teleosts, with special emphasis on flatfish (Pleuronectiforems). Comp Biochem Physiol A 137:447-477.

Whitlock KE, Illing N, Brideau NJ, Smith KM, Twomey S (2006) Development of GnRH cells: Setting the stage for puberty. Mol Cell Endocrinol 254-255:39-50.

(Received 17 February 2013, Received in revised form 4 March 2013, Accepted 12 March 2013) 